\title{
SENSE OF COHERENCE, LOCUS OF CONTROL AND DEPRESSION SYMPTOMS IN ADOLESCENTS WITH TYPE 1 DIABETES
}

\author{
Sylwia Jankowicz, Małgorzata M. Puchalska-Wasyl, and Małgorzata Łysiak
}

Institute of Psychology, John Paul II Catholic University of Lublin

For patients with type 1 diabetes, sense of coherence (SOC), locus of control (LOC) and depression symptoms seem to be important variables in terms of compliance with a treatment regimen. The aim of this article is to describe the functioning of adolescents with type 1 diabetes - to define the common features and differentiating characteristics of the clinical group in comparison with the control group in terms of SOC, LOC and symptoms of depression. The other aim is to check whether LOC mediates the relationship between SOC and depression symptoms in the diabetics group. The study involved 100 adolescents aged 13-17. The clinical group contained adolescents with type 1 diabetes while the control group featured adolescents without diabetes. Antonovsky's Sense of Coherence Scale (SOC-29), the Locus of Control Questionnaire (LOCQ) by Krasowicz and Kurzyp-Wojnarska and the Children's Depression Inventory (CDI) by Kovacs were used. The groups did not differ in their SOC level but varied in the level of depression symptoms and LOC. The clinical and control groups had undetermined and external LOC, respectively. Diabetics also had a lower level of depression symptoms. SOC correlated positively with LOC and negatively with depression symptoms. Additionally, within the clinical group, LOC mediated the relationship between SOC and symptoms of depression. Determining the level of key health variables in type 1 diabetics is important in educating them how

Sylwia Jankowicz, https://orcid.org/0000-0002-2440-745X; Malgorzata M. PuchalSKA-WASYL, https://orcid.org/0000-0003-4295-8308; MALGORZATA ŁYSIAK, https://orcid.org/0000-00028269-4653. Correspondence concerning this article can be addressed to SYLWIA JANKOwICZ, Katolicki Uniwersytet Jana Pawła II w Lublinie, Katedra Psychologii Klinicznej, Al. Racławickie 14, 20-950 Lublin, Poland; email: sylwia.jankowicz@kul.pl.

Approval was obtained from the Research Ethics Committee at the Medical University in Lublin. The procedures used in this study adhere to the tenets of the Declaration of Helsinki. Informed consent was obtained from all individual participants and their parents included in the study.

Handling editor: Przemystaw BĄBEL, Jagiellonian University in Kraków.

Received 11 March 2021. Received in revised form 4 Aug. 2021. Accepted 9 Sept. 2021. Published online 8 Nov. 2021. 
to manage their disease. With regard to adolescents without diabetes, the results confirm the need to intensify activities aimed at monitoring their mental state.

Keywords: type 1 diabetes; adolescence; sense of coherence; symptoms of depression; locus of control.

Adolescence is a time when intense changes occur at all levels of development. Physical, mental, social and spiritual transformations are intended to prepare young people to operate at subsequent stages of life, hence the course of adolescence affects activities undertaken in adult life and overall functioning (Goossens, 2016; Shaffer \& Kipp, 2010). Harmonious development may be disturbed by the appearance of a chronic somatic disease which requires a patient to abandon some life goals and change the current lifestyle, causing serious psychological stress (Kristofferzon et al., 2018). Symptoms of the disease in addition to stress, are often associated with discomfort, pain, impaired physical prowess, and malaise (Jeon et al., 2010). Limitations related to somatic chronic illnesses can make it difficult or even impossible to effectively take on social roles and satisfy needs (Delamater et al., 2014).

It is assumed that about one in ten teenagers suffers from a chronic disease that somehow limits their daily activities (Suris et al., 2004). The most common chronic metabolic disorder in children is type 1 diabetes (Principi et al., 2017). Type 1 diabetes is the result of absolute insulin deficiency due to the destruction or complete dysfunction of pancreatic $\beta$ cells, mostly caused by an autoimmune process (Zheng et al., 2017). A chronic illness that interferes with a teenager's life when intense physiological and mental changes occur, poses a major challenge for both the individual and his or her family as well as the health care team. Therefore, it would seem necessary to determine how chronic disease can affect biopsychosocial developmental processes (Suris et al., 2004). In children with less visible symptoms, more adaptation difficulties are observed than in children struck by a disease with visible symptomatology (Pless \& Perrin, 1985); so, it is worth monitoring the mental state of young diabetics. Children and adolescents with chronic metabolic disease, including type 1 diabetes, more often than children from the control groups, present psychosocial or psychiatric problems, such as depression, anxiety or eating disorders (Delamater et al., 2014).

Most research on the mental functioning of a chronically ill person has been devoted to adults. Many researchers discuss the relationship between diabetes and depression (de Wit \& Snoek, 2011; Duda-Sobczak \& Wierusz-Wysocka, 2011). Currently, the prevailing view is that the clinical picture of depression in the developmental age does not differ from the clinical picture of depression in adults (Trzęsowska-Greszta et al., 2014; Weiss \& Garber, 2003). The axial symptoms of depression include depressed mood as well as loss of interest or pleasure (anhedo- 
nia). Other symptoms may occur: a sense of hopelessness, worthlessness, inappropriate guilt, sleep disturbances, inhibition, reduced energy and the ability to think and concentrate, as well as difficulties in making decisions and overall fatigue (APA, 2013). The risk of developing depression is $4 \%$ among the chronically ill and $2.8 \%$ in the general population (Duda-Sobczak \& Wierusz-Wysocka, 2011). Very high levels of neurotic and depressive tendencies are characteristic of the psychosocial development of chronically ill children (Pilecka, 2002). The prevalence of symptoms of depression among children with type 1 diabetes was $15-20 \%$, but less than $7 \%$ in children without diabetes (de Wit \& Snoek, 2011). According to Kokkonen and Kokkonen (1995), depression is observed 2-3 times more often in adolescents with diabetes than in adolescents without. According to medical staff, $67.9 \%$ of type 1 diabetics have psychological problems, and over $85 \%$ of patients admit that after the diagnosis was given, they felt guilty and helpless, and experienced a high level of distress (Nowogrodzka \& Piasecki, 2010).

The acute deterioration of health caused by diabetes or stress related to the diagnosis may mobilise mental strength and resources necessary to counteract the disease, as well as raise awareness of the need to extend knowledge about it and believe in the possibility to control it. The effectiveness of diabetes treatment always depends on the behavior and actions of children, adolescents, and later-adults with diabetes. Good monitoring with currently used treatments always accompanies purposeful behavior or a healthy lifestyle that a diabetic follows consistently and on a daily basis, during work and recreation (Tatoń, 1995). Proper diet, insulin injections, metabolic self-monitoring is a daily routine. Its success determines the condition of the diabetics, their health, fulfillment of social roles and life goals, and the satisfaction of their needs. It should be added that diabetes is a disease that requires extreme vigilance and self-observation and the diabetes control regime often does not match the psychological characteristics of the needs of an adolescent patient. As adolescence is commonly associated with a rebellious attitude, people may have an image of a teenage patient as non-compliant (Suris et al., 2004). However, this view should not be generalized. It may seem particularly relevant to test the maturity and readiness of young people to administer self-care and take responsibility for themselves. Compliance with a treatment regimen requires appropriate cognitive skills and personal organization, as well as a personal conviction that treatment is necessary and beneficial (Vermeire et al., 2001). In this context, sense of coherence (SOC) and locus of control (LOC) would appear to be important variables in patients. However, few studies have considered the role of SOC in a diabetic patient. Nor have there been any studies on LOC in a group of young diabetics. 
SOC is a person's feeling of certainty that the reality that surrounds them is understandable, coherent, possible to organize (Comprehensibility), and that they have internal and external resources that will allow them to cope with potential life difficulties (Manageability). The individual believes that facing life's challenges has a deeper meaning (Meaningfulness; Antonovsky, 1995; Kirenko \& Byra, 2008). High SOC means being able to deal with tension constructively and promotes good health (Antonovsky, 1995). Therefore, the determination of SOC may contribute to a better planning of a diabetic patient's education (Kurowska \& Figiel, 2009). High SOC is conducive to engaging in pro-health behaviors, positively associated with many measures of health, and negatively with many measures of disease (Kozaka, 2010; Kurowska \& Sulkowska, 2011). Some studies (Kurowska \& Świątkowska, 2009) show that the level of SOC in patients with type 1 diabetes is much lower than the normative values indicated by Antonovsky (1995). A similar and also lower SOC index was obtained in a group of people with type 2 diabetes (Kurowska \& Figiel, 2009). Polish studies show that diabetics with a low level of depression symptoms manifest higher SOC than diabetics with high level of these symptoms (Kurowska et al., 2007; Kurowska \& Świątkowska, 2009). Among adolescents hospitalized in a psychiatric ward, reduced SOC was also found (Bażyńska et al., 2002). Research on the general population shows that the higher the SOC, the stronger the sense of agency and control over one's life. Therefore, SOC can be supported by LOC in the process of dealing with difficult situations (Turecka, 2005).

LOC can be represented on a continuum from external to internal. With external LOC, a person feels that external factors beyond their control (chance, destiny, other people's actions) determine what is happening. With internal LOC, the individual perceives that the result of the action is conditioned by their own behavior or relatively constant personal qualities. The person is convinced that they decide their fate, which implies making further efforts to achieve goals (Galvin et al., 2018). LOC is shaped by individual experience through social learning and undergoes changes with age. As individuals mature, they move from more external to more internal LOC (Gierowski \& Rajtar, 2003). Some studies related to the locus of health control show that type 1 and type 2 diabetics demonstrate a greater conviction about the influence of other people or coincidence on their fate compared to control groups (Basińska et al., 2011; Kurpas et al., 2012; Mućko et al., 2005).

Both SOC and LOC are life-long variables that are largely dependent on life experiences. However, we cannot consider them to be the same. It is particularly necessary to distinguish between LOC and sense of manageability. LOC is a general tendency to perceive a causal relationship between one's own actions and their consequences. It is related to the perception of self-efficacy and determines the extent of an individual's activity. By observing the results of their behavior, individuals make 
assumptions about their effectiveness and on this basis take decisions about further behavior (Rotter, 1966). Manageability is a person's belief that they have sufficient opportunities to meet the requirements of life. It is related to the perception of one's own abilities, but even the awareness of high abilities does not necessarily drive human behavior. SOC appears to be a broader construct than LOC. A high level of SOC promotes an accurate assessment of reality, giving it meaning and opening up new possibilities for action. A high level of SOC may favor a high level of LOC. Comprehensibility, manageability, and meaningfulness can support more mature forms of LOC. In turn, high LOC, thanks to which people attribute successes to themselves and failures to external factors, may protect against the occurrence of symptoms of depression.

Considering that few studies have addressed the role of SOC and LOC in young diabetic patients, and that we do not know of studies examining the relationship between SOC, LOC and depression in type 1 diabetics, we planned our research accordingly. In the context of the above-mentioned results, we posed the following hypotheses:

H1: Adolescents with type 1 diabetes, compared to the control group, are characterized by lower SOC and LOC and the higher level of depression symptoms.

H2: In adolescents with type 1 diabetes, SOC positively correlates with LOC and negatively with symptoms of depression.

H3: In adolescents with type 1 diabetes, LOC mediates the relationship between SOC and symptoms of depression.

\section{METHOD}

\section{Participants}

The research was conducted in Poland. One hundred adolescents aged 13-17 $(M=15.12 ; S D=1.74)$ participated in the study. The subjects formed two equal groups. The clinical group consisted of 50 hospitalized adolescents: 27 girls and 23 boys with type 1 diabetes. The control group consisted of school-age teenagers without diabetes. Information that school students did not have chronic diseases were obtained from teachers. When selecting the control group, the following factors were taken into account: no diagnosed diabetes, gender, and age; hence the proportions of the last two variables in both groups were the same. Most of the respondents (57\%) lived in a city. In 8 people, diabetes had been diagnosed no longer than 2 weeks before the study; the remaining 42 people reported a longer duration of illness 
(13 people -3 years; 11 people -8 years; 18 people —over 8 years). Conversations with these 8 young diabetics' parents revealed that for some time (at least a year) they had been struggling with various disturbing symptoms that hindered their daily functioning, causing distress and anxiety. Therefore, we believe that despite a fresh diagnosis, their experience qualifies for an analysis of the relationship between SOC, LOC and potential symptoms of depression in the context of health problems. All the diabetics were treated pharmacologically ( 1 person with an insulin pump; the rest with oral medications). Within the clinical group, 10 people reported having an additional chronic disease (most often hypothyroidism). The procedure was approved by the Research Ethics Committee at the Medical University in Lublin.

\section{Measures}

\section{The Sense of Coherence Scale (SOC-29)}

It is a method measuring sense of coherence (Antonovsky, 1987). The method consists of 29 items rated on a 7-point Likert scale from 1 (strongly disagree) to 7 (strongly agree). The items form three subscales: (1) Comprehensibility measures the degree to which an individual treats incoming stimuli as consistent and ordered (11 items); (2) Manageability determines the extent to which the individual perceives the resources available to him/her as sufficient to meet the requirements of the incoming stimuli (10 items); (3) Meaningfulness determines the extent to which a person feels that their life makes sense, and the requirements they have to face are worth the effort and commitment ( 8 items). The Cronbach's alpha indices calculated for SOC-29 in this study are presented in Table 3. It should be noted that SOC-29 is a method intended for adults; however, it is also successfully used among adolescents. Since there are few studies on SOC among youth with diabetes, we opted for full scale measurements instead of using SOC-13 (a short version for adolescents). All the items of SOC-29 were fully understandable by the participants of our research.

\section{The Locus of Control Questionnaire (LOCQ)}

This is a method measuring the location of control designed by Krasowicz and Kurzyp-Wojnarska (1990). It consists of 10 buffer items and 36 diagnostic items, 18 items each in the Success Scale (S) and Failure Scale (F). It is possible to calculate an overall score. The person responds by choosing one of two possible answers (rated on a $0-1$ scale), one of which represents internal LOC and the other external LOC. The obtained results are interpreted as follows: on the $\mathrm{S}$ scale, a raw score of 
0-10 indicates external LOC, a raw score of 11-13 indicates undetermined LOC, and a raw score of 14-18 indicates external LOC. On the F scale, a raw score of 0-11 indicates external LOC, 12-14 undetermined LOC, and a raw score of 15-18 indicates internal LOC. On the $\mathrm{S}$ and $\mathrm{F}$ scales, the raw scores taken together are as follows: 0-22 for external LOC; 23-28 for undetermined LOC; $29-36$ for internal LOC. The Cronbach's alpha indices calculated for LOCQ in this study are presented in Table 3.

\section{The Children's Depression Inventory (CDI)}

This is a 27-item youth report symptom scale designed by Kovacs (1992). It is used to study depression symptoms. In our study a version adapted by Oleś (1995) was used. CDI items are divided into affective, cognitive, motivational/withdrawal, and vegetative categories like: sadness, anhedonia, thoughts of suicide, sleep and appetite disorders. Each item covers one symptom. The respondent has three alternative answers (scored 0,1 , or 2 ) and chooses one that best describes them over the past two weeks. The global score ranges from 0 to 54: the higher the number, the greater the level of depression symptoms (Oleś, 2010). A final score of 13 or higher indicates at least mild depression, and a score higher than 19 indicates severe depression (Kovacs, 2003). The method has 5 subscales: Negative Mood ( 6 items; $\alpha=0.76$ ), Interpersonal Problems ( 4 items; $\alpha=0.32$ ), Ineffectiveness ( 4 items; $\alpha=0.69$ ), Anhedonia ( 8 items; $\alpha=0.78$ ), and Negative Self- Esteem (5 items; $\alpha=0.39$ ). Due to the very low reliability of some subscales, only the general score was analyzed. The Cronbach's alpha index calculated for the general CDI score in this study is presented in Table 3 .

The research was carried out using the paper-pencil method. In the clinical group it was individual. People without diabetes were studied in small groups. It took 20 to 45 minutes to complete the set of questionnaires.

\section{Statistical Analysis}

All the analyses in our study were performed on raw scores. First, we calculated coefficients of kurtosis, skewness, and the Shapiro-Wilk test for each construct. Given that the values for asymmetry and kurtosis between -2 and +2 are considered acceptable to prove normal univariate distribution (George \& Mallery, 2010), we could treat all the variables as normally distributed (Table 1 ). 
Table 1

Distribution of Scores on Variables

\begin{tabular}{lrrrrrrrr}
\hline \multicolumn{1}{c}{ Variables } & Min & Max & $M$ & $S D$ & Skewness & Kurtosis & S-W & $p_{\text {S-W }}$ \\
\hline SOC-29 & 80 & 190 & 132.82 & 27.10 & 0.43 & -0.45 & .136 & .02 \\
Comprehensibility & 53 & 169 & 123.08 & 26.91 & -0.53 & 0.19 & .108 & .20 \\
& 23 & 66 & 46.16 & 9.69 & 0.29 & -0.19 & .128 & .04 \\
Manageability & 15 & 65 & 43.30 & 10.49 & 0.00 & 0.36 & .116 & .09 \\
& 27 & 70 & 47.60 & 10.75 & 0.38 & -0.39 & .111 & .17 \\
Meaningfulness & 18 & 63 & 44.80 & 10.61 & -0.58 & -0.20 & .108 & .20 \\
& 12 & 56 & 39.06 & 9.78 & -0.29 & 0.33 & .105 & .20 \\
LOCQ & 10 & 50 & 34.98 & 9.53 & -0.66 & 0.03 & .119 & .07 \\
& 9 & 33 & 24.64 & 5.76 & -0.33 & -0.53 & .143 & .01 \\
Success & 9 & 33 & 22.06 & 5.71 & -0.12 & -0.74 & .105 & .20 \\
& 5 & 17 & 12.12 & 3.18 & -0.52 & -0.55 & .098 & .20 \\
Failure & 14 & 16 & 11.16 & 3.15 & -0.32 & -0.60 & .112 & .16 \\
& 4 & 18 & 12.52 & 3.31 & -0.42 & -0.50 & .136 & .02 \\
CDI & 3 & 17 & 10.90 & 3.38 & -0.31 & -0.41 & .124 & .05 \\
& 2 & 28 & 13.02 & 7.57 & 0.24 & -1.32 & .187 & .00 \\
& 3 & 48 & 16.84 & 10.06 & 1.22 & 1.46 & .145 & .01 \\
\hline
\end{tabular}

Note. SOC-29 = Sense of Coherence Scale; LOCQ = Locus of Control Questionnaire; CDI = Children's Depression Inventory; $\mathrm{S}-\mathrm{W}=$ Shapiro-Wilk test; $p_{\mathrm{S}-\mathrm{W}}=$ significance level for the Shapiro-Wilk test; for each variable: the first line is a group of diabetics; the second line is the control group.

Next, to verify Hypothesis 1 we performed $t$-Student test to compare the differences between the clinical and control groups in terms of the analyzed variables (Table 2).

\section{Table 2}

Comparison of Groups in Terms of SOC, LOC and Depression Symptoms: Student's t-test

\begin{tabular}{lccccccc}
\hline & \multicolumn{2}{c}{ Clinical group } & \multicolumn{2}{c}{ Control group } & \multicolumn{3}{c}{ Student's $t$-test } \\
\hline & $M$ & \multicolumn{1}{c}{$S D$} & \multicolumn{1}{c}{$M$} & \multicolumn{1}{c}{$S D$} & \multicolumn{1}{c}{$t$} & $p$ & Cohen's $d$ \\
\hline SOC-29 & 132.82 & 27.10 & 123.08 & 26.91 & 1.80 & .074 & 0.36 \\
Comprehensibility & 46.16 & 9.69 & 43.30 & 10.49 & 1.42 & .160 & 0.28 \\
Manageability & 47.60 & 10.75 & 44.80 & 10.61 & 1.31 & .193 & 0.26 \\
Meaningfulness & 39.06 & 9.78 & 34.98 & 9.53 & 2.11 & .037 & 0.42 \\
LOCQ & 24.64 & 5.76 & 22.06 & 5.71 & 2.25 & .027 & 0.45 \\
Success & 12.12 & 3.18 & 11.16 & 3.15 & 1.52 & .133 & 0.30 \\
Failure & 12.52 & 3.31 & 10.90 & 3.38 & 2.42 & .017 & 0.48 \\
CDI & 13.02 & 7.57 & 16.84 & 10.06 & -2.15 & .034 & 0.43 \\
\hline
\end{tabular}

Note. SOC-29 = Sense of Coherence Scale; LOCQ = Locus of Control Questionnaire; CDI = Children's Depression Inventory. 
Additionally, to verify Hypothesis 2, we calculated Pearson bivariate correlations between the SOC-29, LOCQ, and CDI scales and subscales (Table 3).

Table 3

Correlations Among Variables (Pearson's r) and Internal Consistency

\begin{tabular}{|c|c|c|c|c|c|c|c|c|c|}
\hline & Variables & 1 & 2 & 3 & 4 & 5 & 6 & 7 & 8 \\
\hline 1 & SOC-29 & - & & & & & & & \\
\hline \multirow[t]{2}{*}{2} & Comprehensibility & $.86^{* *}$ & - & & & & & & \\
\hline & & $.86^{* *}$ & & & & & & & \\
\hline \multirow[t]{2}{*}{3} & Manageability & $.94 * *$ & $.72 * *$ & - & & & & & \\
\hline & & $.92 * *$ & $.69^{* *}$ & & & & & & \\
\hline \multirow[t]{2}{*}{4} & Meaningfulness & $.89^{* *}$ & $.60^{* *}$ & $.79 * *$ & - & & & & \\
\hline & & $.85^{* *}$ & $.56^{* *}$ & $.72 * *$ & & & & & \\
\hline \multirow[t]{2}{*}{5} & LOCQ & $.49^{* *}$ & $.31 *$ & $.47 * *$ & $.53 * *$ & - & & & \\
\hline & & $.54 * *$ & $.34 *$ & $.54 * *$ & $.55^{* *}$ & & & & \\
\hline \multirow[t]{2}{*}{6} & Success & $.45^{* *}$ & $.30^{*}$ & $.41 * *$ & $.48^{* *}$ & $.88^{* *}$ & - & & \\
\hline & & $.58^{* *}$ & $.42 * *$ & $.53 * *$ & $.58^{* *}$ & $.86^{* *}$ & & & \\
\hline \multirow[t]{2}{*}{7} & Failure & $.42 * *$ & .24 & $.43 * *$ & $.46^{* *}$ & $.89^{* *}$ & $.57^{* *}$ & - & \\
\hline & & $.37 * *$ & .17 & $.42 * *$ & $.40^{* *}$ & $.88^{* *}$ & $.53^{* *}$ & & \\
\hline \multirow[t]{3}{*}{8} & CDI & $.77^{* *}$ & $.56^{* *}$ & $.74 * *$ & $.76^{* *}$ & $.58^{* *}$ & $.51^{* *}$ & $.50^{* *}$ & - \\
\hline & & $.72 * *$ & $.51^{* *}$ & $.73 * *$ & $.66^{* *}$ & $.58 * *$ & $.65^{* *}$ & $.37 * *$ & \\
\hline & $\alpha$ & .92 & .79 & .82 & .85 & .80 & .67 & .73 & .89 \\
\hline
\end{tabular}

Note. SOC-29 = Sense of Coherence Scale; LOCQ = Locus of Control Questionnaire; CDI = Children's Depression Inventory. For each variable, the first line refers to a group of diabetics, and the second line to the control group $* p<.05 ; * * p<.01 ; \alpha$ for the entire research sample.

In order to verify Hypothesis 3, mediation analyses were performed. We used PROCESS (Hayes, 2018), a regression-based path-analytic framework, and estimated indirect effects and bias-corrected confidence intervals. We tested the significance of indirect effects using the bootstrapping procedure. Standardized indirect effects were computed for each of 5,000 bootstrapped samples, and the $95 \%$ confidence intervals were determined. In our analyses we tested SOC as predictors of depression symptoms, and LOC as a mediator. 


\section{RESULTS}

It was found that adolescents with type 1 diabetes are characterized by a higher level of LOC (also on the Failure Scale) and a lower level of depression symptoms. There were no group differences in terms of SOC except meaningfulness (Table 2). Thus, Hypothesis 1 was not confirmed.

Additionally, it turned out that within the group of adolescents with diabetes, the sense of coherence (both the overall SOC-29 score and the subscale scores) and the localization of control (both the overall LOCQ score and the subscale scores) were positively related. They were also strongly negatively related to depression symptoms (CDI). Thus, Hypothesis 2 was confirmed. The same relationships occur in the group of adolescents without diabetes (Table 3).

In our mediation analyses conducted for the clinical group (Figure 1), we found a significant negative indirect effect of SOC on symptoms of depression through LOC. This means that higher SOC was conducive to higher LOC, which reduced depression symptoms. Thus, Hypothesis 3 was confirmed.

\section{Figure 1}

Locus of Control as Mediator of Relationship Between Sense of Coherence and Depression Symptoms-Standardized Coefficients

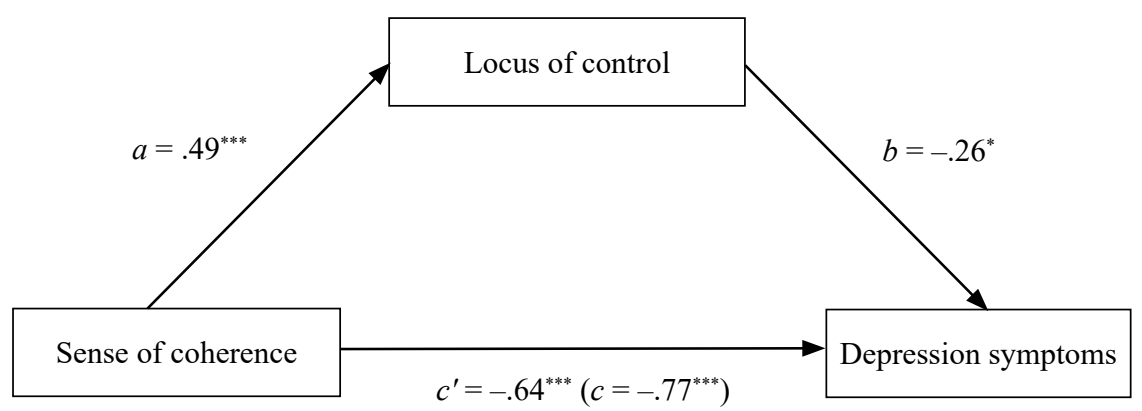

Note. $a=$ effect of the predictor on the mediator; $b=$ effect of the mediator on the outcome; $c^{\prime}=$ direct effect of predictor on outcome while controlling for the mediator; $c=$ total effect.

${ }^{*} p<.05 ;{ }^{* *} p<.01 ;{ }^{* * *} p<.001$. 


\section{DISCUSSION}

The aim of the presented study was to describe the functioning of adolescents with type 1 diabetes - to define common and differentiating features of the clinical group compared to a group of healthy adolescents in terms of SOC, LOC and depression symptoms; and to check whether LOC mediates the relationship between SOC and symptoms of depression in the clinical group. Contrary to Hypothesis 1, our analyses showed that overall SOC did not vary in the studied groups. SOC is a variable depending on the type of disease. According to Rynkiewicz-Andryśkiewicz et al. (2014), if a disease does not directly threaten human life and health, only a slight reduction in SOC is observed. With proper self-care and systematic glycemic control, diabetes is a manageable disease (Kirenko \& Byra, 2008). On the other hand, diabetes mellitus is a disease in which the effectiveness of glucose control is variable - there are situations where fluctuations in glucose levels are more significant. Long-term diabetes, even with super effective management, increases the risk of comorbidities like coronary heart disease or vision problems (Tatoń, 1995). The fact is that in our study the global SOC index in the clinical group remained within the limits of the norms defined by Antonovsky (130-60). This may be for two reasons. First, due to the use of defense mechanisms, especially in the early stages of the disease. Second, from successful adaptation to the disease. Most of our respondents with diabetes are people with a longer history of the disease. It is possible that these adolescents have already successfully adapted to it. During the interviews, the participants also indicated that they felt supported by their parents. A supportive environment, proper medical care and emphasis on making the patient aware of the disease and its treatment process are conducive to the development of an adequate cognitive representation of the disease (Taton, 1995). Preventing acute relapses of the disease (by selecting appropriate treatment measures) helps the patient to maintain the belief that the situations they encounter are in some sense predictable and explainable, and that they have sufficient resources to deal with them, because it is worth the effort. Since coherence is a health dependent variable (Antonovsky, 1995), it is puzzling that adolescents in the control group not only did not score higher than the clinical group, but even scored significantly lower on meaningfulness. A similar result was obtained by Garbacz (see Kirenko \& Byra, 2008), where type 1 diabetics, compared to healthy people, had a higher comprehensibility and meaningfulness index. How to explain this? First, the lack of diagnosed diabetes among the control group does not exclude the presence of other chronic diseases, and thus, does not make these respondents a priori healthy group. Second, it seems that diabetics can receive more support from parents, healthcare professionals and 
sick people's associations. According to Antonovsky (1995), SOC consists of both internal, personal qualities, and some external resources that people or institutions from the environment have at their disposal. Not only teenagers with diabetes but also somatically healthy teenagers need support. The turbulent process of maturation may raise many questions and doubts about what is happening to them and how their future will look. If adolescents are left alone with these questions, they may have the impression that the surrounding world is chaotic and difficult to organize, which will manifest as lowered SOC. Research shows that SOC correlates with health-related behavior (Kommuri et al., 2016; Thomas et al., 2020). Meaningfulness is shaped as a result of an individual's active participation in decision-making (Antonovsky, 1995). It is likely that young diabetics can develop this aspect of SOC by performing the tasks entrusted to them and gradually taking responsibility for their health.

Additionally, contrary to our Hypothesis 1, we found that adolescents with type 1 diabetes had higher LOC than adolescents without diabetes. It is known that LOC is shaped by individual experience (social learning). As a person matures, they move from more external LOC to more internal LOC, with mental age playing an important role rather than biological age (Krasowicz \& Kurzyp-Wojnarska, 1990). The obtained result can be explained by the fact that adolescents with diabetes, compared to healthy ones, probably take responsibility for their own lives earlier. Young diabetics start leading a conscious and attentive lifestyle with a medical diagnosis, because they are obliged to take care of their health in a special way. Including adolescents in activities related to the treatment process, making decisions in important matters, following medical recommendations and sincerely engaging them in solving problems related to their health, fosters their conviction about the possibility of self-determination, which provides the basis for achieving higher LOC.

Our research has also shown, contrary to Hypothesis 1, that adolescents with type 1 diabetes have a lower index of depression symptoms than the control group, although in both cases it suggests mild depression. It is known that patients with diabetes are relatively often diagnosed with depression symptoms, increased pessimism, mood variability, or a sense of uncertainty and powerlessness (Skłodowski \& Janiszewska, 1998). The frequency of depression symptoms in diabetics ranges from 8.5 to $32.5 \%$ (Suwalska \& Łojko, 2004). Chronic and life-threatening diseases can be a source of distress, which consequently leads to the appearance of depression symptoms (Pużyński, 2005). Indeed, the level of depression symptoms in young diabetics in our study can be classified as mild depression. Many sources report that the prevalence of depression among diabetics type 1 and type 2 is higher compared to the people without diabetes (Gendelman et al., 2009; van Duinkerken et al., 2020). At the same time, we found that adolescents without diabetes show significantly higher levels of depressive symptoms. Adolescence is associated with 
the accumulation of intense biological, social and psychological changes. It seems that adolescents with diabetes are more likely to receive ongoing care from both medical personnel and those closest to them, who can watch over the process of biological and psychological changes. Environmental control over the well-being of healthy adolescents tends to be weaker and therefore, the appearing symptoms may not be noticeable to loved ones. The control group was not asked about possible critical events that could trigger depressive symptoms. It is worth adding that most of the clinical group had long-term diabetes. The longer the duration of the disease, the higher the level of acceptance and adaptation to living with it (Oleś, 2010), which can alleviate the occurrence of possible depressive symptoms. As a result, young diabetics may have the lower level of depressive symptoms than healthy adolescents.

Hypothesis 2 was confirmed. We found that SOC among adolescents with type 1 diabetes is positively related to LOC. People with high SOC have many common characteristics with people with high LOC (Turecka, 2005). A high level of SOC promotes an accurate assessment of reality. The individual begins to organize incoming stimuli, which cease to be an incomprehensible information noise, accumulate resources needed for effective coping, and boldly and more willingly face demands. Internal LOC involves making an effort to achieve a goal. People with inner control have a developed sense of responsibility, which translates into active participation in the process of recovery and rehabilitation (Stenström et al., 2011). Adolescents with type 1 diabetes, following the recommendations of medical staff, can see the desired results. Being convinced of the effectiveness of one's own actions can lead to further improvements in health-related behavior and increase the belief in one's own competence, which in turn improves manageability (SOC aspect). It is possible that young diabetics' responsibility for their own health is not only related with the commitment and effort directed towards the treatment process, but also with the conviction that it makes sense to fight the disease. This thinking seems to be confirmed by a significantly higher meaningfulness score (SOC aspect) in the clinical group. Our study also showed that SOC among adolescents with type 1 diabetes is negatively related to depression symptoms. Many studies confirm a negative correlation between coherence and depression (Cilliers, 2003; Fusz et al., 2017; Kurowska \& Ciesielska, 2013; Lewicka et al., 2014; Schäfer et al., 2018).

In line with Hypothesis 3, our study also showed that the negative relationship between SOC and depression symptoms is mediated by LOC in the clinical group. LOC can be understood as a generalized belief of an individual about their ability to exercise behavioral and cognitive control, which promotes a sense of security (Rotter, 1966). Specific beliefs emerge through the learning process, so that an individual's subsequent behaviors that produce expected outcomes cause a gradual change in LOC from external to internal. Diabetics have experience of confronting 
crisis (e.g. chronic disease). Probably, the reward in the form of improvement in their health as a result of undertaking health-related behaviors, strengthens their belief that they have an impact on their own life. This belief extends to future events, so the appearance of further threatening symptoms e.g., depression, may trigger their conviction that symptoms can be controlled and, consequently, the actual control of these symptoms.

\section{LIMITATIONS}

Our research has some limitations. Firstly, the study was correlational and comparative in nature, which makes it impossible to draw causal conclusions. Another limitation is the small group size and poor health monitoring among adolescents in the control group. Information about the lack of chronic diseases-in particular diabetes - was obtained primarily from school staff and teachers, whereas it is conceivable that parents do not inform the school about their child's illnesses. It is possible that despite the anonymity of the participants, they may have concealed their chronic illness. Thus, in future research, a preliminary interview with the adolescent's legal guardians may be a good solution. In addition, it would be important to control possible critical events occurring in a teenager in the last year, which could affect his/her well-being and the severity of depression symptoms.

A more detailed diagnosis including the somatic state of people with diabetes should also be made (e.g. effectiveness in coping with the disease symptoms, the frequency of experienced hypoglycemia with loss of consciousness, measuring effectiveness of glycemic control HbA1c results). Unfortunately, we did not have access to medical records at the time.

\section{IMPLICATIONS}

Our study has some implications. Determining the level of key health variables in patients with type 1 diabetes is important in educating them how to manage their disease and in identifying the extent and form of the support needed. We propose that young people with diabetes should participate in group education (small groups of 6-10 people) conducted in a structured manner. Group selection could be based on criteria such as age, disease characteristics and treatment options. Within the scope of a "health school", a young patient would systematically participate in classes prepared in accordance with the overall plan, where they would extend 
their knowledge about living with diabetes and train psychosocial and intrapsychic skills in relation to SOC, LOC, and the prevention of early symptoms of mood disorders. The knowledge of the relationship between SOC, LOC, and depression symptoms, provides an opportunity to prepare a preventive program in order to secure or strengthen the competences necessary in the process of adaptation to the disease. The future research on causal relationships between these variables can facilitate the development of therapeutic programs aimed at building and rebuilding competences disturbed as a result of experiencing a disease that changes the current rhythm of life. With regard to the group of adolescents without diabetes, the obtained data confirm the need to intensify activities aimed at monitoring their mental state. The absence of a diagnosed disease does not necessarily mean a high level of well-being. Adolescence is associated with many important changes in the lives of young people. Increasing attention to seemingly healthy adolescents is conducive to faster and more effective interventions, offers a sense of support and is a protective factor against the emergence of psychosomatic disorders.

\section{CRediT Author statement}

SYLWIA JANKOWICZ (50\%): conceptualization, methodology, investigation, resources, formal analysis, writing (original draft), visualization.

Malgorzata M. Puchalska-Wasyl (30\%): validation, formal analysis, writing (review and editing), supervision.

MAŁGORZATA ŁYSIAK (20\%): conceptualization, formal analysis, project administration.

\section{REFERENCES}

Antonovsky, A. (1987). Unraveling the mystery of health: How people manage stress and stay well. Jossey-Bass.

Antonovsky, A. (1995). Rozwiktanie tajemnicy zdrowia. Jak radzić sobie ze stresem i nie zachorować [Unraveling the mystery of health. How to deal with stress and not become ill]. Zakład Wydawniczy Letter Quality.

American Psychiatric Association. (2013). Diagnostic and Statistical Manual of Mental Disorders DSM-5, fifth edition. American Psychiatric Association Publishing.

Basińska, M., Maćkowska, P., \& Listwan, A. (2011). Przekonania o umiejscowieniu kontroli zdrowia chorych na cukrzycę typu 1 a zachowania zdrowotne [Beliefs about the location of control health of patients with type 1 diabetes and health behavior]. Diabetologia Praktyczna, 12(4), 151-159.

Bażyńska, K., Bronowska, Z., Namysłowska, I., \& Żechowski, C. (2002). Poczucie koherencji (SOC) u pacjentów psychiatrycznego oddziału młodzieżowego [Sense of coherence (SOC) in patients of a psychiatric adolescent unit]. Psychiatria Polska, 36(1), 121-131. 
Cilliers, F. (2003). Burnout and salutogenic functioning of nurses. Curationis, 26, 62-74. https://doi. org/10.4102/curationis.v26i1.1296

Delamater, A., de Wit, M., McDarby, V., Malik, J., \& Acerini, C. (2014). Psychological care of children and adolescents with type 1 diabetes. Pediatric Diabetes, 15(20), 232-244. https://doi.org/10.1111/ pedi. 12736

de Wit, M., \& Snoek, F. (2011). Depressive symptoms and unmet psychological needs of Dutch youth with type 1 diabetes: Results of a web-survey. Pediatric Diabetes, 12(3), 172-176. https://doi. org/10.1111/j.1399-5448.2010.00673.x

Duda-Sobczak, A., \& Wierusz-Wysocka, B. (2011). Cukrzyca a choroby psychiczne [Diabetes and mental diseases]. Psychiatria Polska, 65(4), 589-598.

Fusz, K., Tóth, Á., Varga, B., Rozmann, N., Oláh, A., \& Tudományegyetem, P. (2017). Different work schedules of nurses in Hungary and their effects on health. Ideggyogyaszati Szemle-Clinical Neuroscience, 70, 136-139. https://doi.org/10.18071/isz.70.0136

Galvin, B. M., Randel, A. E., Collins, B. J., \& Johnson, R. E. (2018). Changing the focus of locus (of control): A targeted review of the locus of control literature and agenda for future research. Journal of Organizational Behavior, 39(7), 820-833. https://doi.org/10.1002/job.2275

Gendelman, N., Snell-Bergeon, J., McFann, K., Kinney, G., Wadwa, R., Bishop, F., Rewers, M., \& Maahs, D. (2009). Prevalence and correlates of depression in individuals with and without type 1 diabetes. Diabetes Care, 32(4), 575-579. https://doi.org/10.2337/dc08-1835

George, D., \& Mallery, M. (2010). SPSS for Windows step by step: A simple guide and reference, 17.0 update. Pearson.

Gierowski, J., \& Rajtar, T. (2003). Chosen factors influencing the locus of control in perpetrators of criminal acts. Problems of Forensic Sciences, 53, 129-138.

Goossens, L. (2016). Theories of adolescence. In S. Jackson \& L. Goossens (Eds.), Handbook of Adolescent Development (pp. 11-29). Routledge.

Hayes, A. F. (2018). Introduction to mediation, moderation, and conditional process analysis: A regression-based approach (2 ed.). Guilford Press.

Jeon, Y. H., Kraus, S. G., Jowsey, T., \& Glasgow, N. J. (2010). The experience of living with chronic heart failure: A narrative review of qualitative studies. BMC Health Services Research, 10(77). https://doi.org/10.1186/1472-6963-10-77

Kirenko, J., \& Byra, S. (2008). Zasoby osobiste w chorobach psychosomatycznych [Personal resources in psychosomatic diseases]. Wydawnictwo UMCS.

Kokkonen, K., \& Kokkonen, E. R. (1995). Mental health and social adaptation in young adults with juvenile-onset diabetes. Nordic Journal of Psychiatry, 49(3), 175-182. https://doi. org/10.3109/08039489509011903

Kommuri, S., Dolar, D., Suhas, K., Bandari, S., \& Madupu, P. (2016). Correlation of sense of coherence with oral health behaviors, socioeconomic status, and periodontal status. Journal of Indian Society of Periodontology, 20(4), 453-459. https://doi.org/10.4103/0972-124X.193166

Kovacs, M. (1992). Children's Depression Inventory Manual. Multi-Health Systems.

Kovacs, M. (2003). Children's Depression Inventory: Technical manual update. Multi-Health Systems.

Kovacs, M., Goldston, D., Obrosky, D., \& Bonar, L. (1997). Psychiatric disorders in youths with IDDM: Rates and risk factors. Diabetes Care, 20, 36-44. https://doi.org/10.2337/diacare.20.1.36

Kozaka, J. (2010). Radzenie sobie ze stresem choroby - współczesne koncepcje teoretyczne [Dealing with the stress of disease: Modern theoretical concepts]. Psychoonkologia, 2, 60-69.

Krasowicz, G., \& Kurzyp-Wojnarska, A. (1990). Kwestionariusz do badania poczucia kontroli (KBPK). Podręcznik [Questionnaire for testing the sense of control (KBPK). Manual]. ZP. 
Kristofferzon, M. L., Engström, M., \& Nilsson, A. (2018). Coping mediates the relationship between sense of coherence and mental quality of life in patients with chronic illness: A cross-sectional study. Quality of Life Research, 27, 1855-1863. https://doi.org/10.1007/s11136-018-1845-0

Kurowska, K., Brzyska-Wilusz, B., Felsmann, M., \& Głowacka, M. (2007). Depresyjność a poczucie koherencji u osób chorych z 1 typem cukrzycy [Depressiveness and the sense of coherence in patients with type 1 diabetes]. Nowiny Lekarskie, 76(5), 406-413.

Kurowska, K., \& Ciesielska, L. (2013). Depression and a sense of coherence in case of people with anxiety disorders. Psychiatria i Psychologia Kliniczna, 13(1), 40-49.

Kurowska, K., \& Figiel, O. (2009). Poczucie koherencji a zachowania zdrowotne u osób z rozpoznaną cukrzycą typu 2 [Sense of coherence and health behavior in people diagnosed with type 2 diabetes]. Nowiny Lekarskie, 78(3-4), 197-205.

Kurowska, K., \& Sulkowska, J. (2011). Poczucie koherencji a zachowania zdrowotne wśród pensjonariuszy Domu Pomocy Społecznej (DPS) - badania wstępne [Sense of coherence and health behavior in residents of a nursing home (DPS): Preliminary research]. Psychogeriatria Polska, $8(2), 73-80$.

Kurowska, K., \& Świątkowska, T. (2009). Poczucie koherencji (SOC) a preferowane style radzenia sobie z chorobą u osób z rozpoznaniem cukrzycy typu 1 [Sense of coherence (SOC) and preferred styles of coping with the disease in people diagnosed with type 1 diabetes]. Nowiny Lekarskie, 78(3-4), 191-196.

Kurpas, D., Kusz, J., Jedynak, T., \& Mroczek, B. (2012). Umiejscowienie kontroli zdrowia u osób ze schorzeniami przewlekłymi [Location of health control in people with chronic diseases]. Family Medicine \& Primary Care Review, 14(2), 186-188.

Lewicka, M., Makara-Studzińska, M., Sulima, M., \& Wiktor, H. (2014). Intensification of anxiety and depression, and personal resources among women during the peri-operative period. Annals of Agricultural and Environmental Medicine, 21(1), 91-97.

Mućko, P., Kokoszka, A., \& Skłodowska, Z. (2005). Porównanie stylów radzenia sobie z chorobą, występowania objawów depresyjnych i lękowych oraz lokalizacji poczucia kontroli u chorych na cukrzycę typu 1 i 2 [Comparison of illness coping styles, the occurrence of depressive and anxiety symptoms and the locus of control in patients with type 1 and 2 diabetes]. Diabetologia Praktyczna, 6(5), 240-249.

Nowogrodzka, A., \& Piasecki, B. (2010). Funkcjonowanie psychologiczne osób z cukrzycą [Psychological functioning of people with diabetes]. In M. Cybulski \& W. Strzelecki (Eds.), Psychologia w naukach medycznych [Psychology in medical science] (pp. 140-150). Wydawnictwo Naukowe Uniwersytetu Medycznego im. Karola Marcinkowskiego.

Oleś, M. (2010). Jakość życia młodzieży w zdrowiu $i$ w chorobie [The quality of life of young people in health and disease]. Wydawnictwo KUL.

Oleś, M. (1995). Pomiar depresji u dzieci: przegląd metod [Measuring depression in children: A review of methods]. Roczniki Filozoficzne, 63(4), 147-170.

Pilecka, W. (2002). Przewlekła choroba somatyczna w życiu i rozwoju dziecka. Problemy psychologiczne [Chronic somatic disease in the life and development of a child. Psychological problems]. Wydawnictwo Uniwersytetu Jagiellońskiego.

Pless, I. B., \& Perrin, J. M. (1985). Issues common to a variety of illnesses. In N. Hobbs \& J. M. Perrin (Eds.), Issues in the care of children with chronic illness: A sourcebook on problems, services, and policies (pp. 41-60). Jossey-Bass.

Principi, N., Berioli, M. G., Bianchini, S., \& Esposito, S. (2017). Type 1 diabetes and viral infections: What is the relationship? Journal of Clinical Virology, 96, 26-31. https://doi.org/10.1016/j. jcv.2017.09.003 
Pużyński, S. (2005). Depresje i zaburzenia afektywne [Depressions and affective disorders]. Wydawnictwo Lekarskie PZWL.

Rotter, J. (1966). Generalized expectancies for internal versus external control of reinforcement. Psychological Monographs, 80, 1-28.

Rynkiewicz-Andryśkiewicz, M., Andryśkiewicz, P., Curyło, M., \& Czernicki J. (2014). Analiza przydatności oceny poziomu poczucia koherencji w chorobach somatycznych i psychicznych [Analyzing the utility value of testing the sense of coherence in somatic and mental diseases]. Przeglad Medyczny Uniwersytetu Rzeszowskiego i Narodowego Instytutu Leków w Warszawie, 4, 365-374.

Schäfer, S. K., Lass-Hennemann, J., Groesdonk, H., Volk, T., \& Michael, T. (2018). Mental Health in Anesthesiology and ICU Staff: Sense of Coherence Matters. Frontiers in Psychiatry, 9, 440. https://doi.org/10.3389/fpsyt.2018.00440

Shaffer, D. R., \& Kipp, K. (2010). Developmental Psychology. Childhood and Adolescence. Wadsworth Publishing.

Skłodowski, H., \& Janiszewska, L. (1998). Psychospołeczne problemy chorych na cukrzycę insulinozależna [Psychosocial problems of patients with insulin-dependent diabetes]. In G. Dolińska-Zygmunt \& J. Lazowski (Eds.), Ku lepszemu funkcjonowaniu w zdrowiu i chorobie [Towards better functioning in health and disease] (pp. 241-245). Wydawnictwo Akademii Wychowania Fizycznego.

Suris, J. C., Michaud, P. A., \& Viner, R. (2004). The adolescent with a chronic condition. Part I: Developmental issues. Archives of Disease Childhood, 89, 938-942. https://doi.org/10.1136/ adc. 2003.045369

Stenström, U., Wikby, A., Andersson, P-O., \& Rydén, O. (2011). Relationship between locus of control beliefs and metabolic control in insulin-dependent diabetes mellitus. British Journal of Health Psychology, 3(1), 15-25. https://doi.org/10.1111/j.20448287.1998.tb00552.x

Suwalska, A., \& Łojko, D. (2004). Zaburzenia psychiczne w chorobach endokrynnych i ich leczenie [Mental disorders in endocrine diseases and their treatment]. Terapia, 12, 25-29.

Tatoń, J. (1995). Cukrzyca. Nauczanie samoopieki [Diabetes. Teaching self-care]. PWN.

Thomas, K., Nilsson, E., Festin, K., Henriksson, P., Lowén, M., Löf, M., \& Kristenson, M. (2020). Associations of psychosocial factors with multiple health behaviors: A population-based study of middle-aged men and women. International Journal of Environmental Research and Public Health, 17(4), 1239. https://doi.org/10.3390/ijerph17041239

Turecka, M. (2005). Czynniki zwiększające ryzyko i zapobiegające przemocy seksualnej [Factors increasing the risk and factors preventing sexual violence]. Seksuologia Polska, 3(2), 43-51.

Weiss, B., \& Garber, J. (2003). Developmental differences in the phenomenology of depression. Development and Psychopathology, 15(2), 403-430. http://doi.org/10.1017/S0954579403000221

van Duinkerken, E., Moreno A. B., Eto, F. N., Lotufo, P., Barreto, S. M., Giatti, L., Viana, M. C., Nunes, M. A., Chor, D., \& Griep, R. H. (2020). Biopsychosocial factors associated with a current depressive episode in diabetes: The ELSA-Brasil study. Diabetic Medicine, 37(10), 1742-1751. https://doi.org/10.1111/dme.14349

Vermeire, E., Hearnshaw, H., Van Royen, P., \& Denekens, J. (2001). Patient adherence to treatment: three decades of research. A comprehensive review. Journal of Clinical Pharmacy and Therapeutics, 26, 331-342. https://doi.org/10.1046/j.1365-2710.2001.00363.x

Zheng, Y., Wang, Z., \& Zhou, Z. (2017). miRNAs: Novel regulators of autoimmunity mediated pancreatic $\beta$-cell destruction in type 1 diabetes. Cellular \& Molecular Immunology, 14, 488-496. https://doi.org/10.1038/cmi.2017.7 